\title{
Arðbært heilbrigðiskerfi
}

Í skugga langra biðlista eftir lífsnauðsynlegum aðgerðum, langpreytts starfsfólks, margra vikna og mánaða biðar eftir nauðsynlegri læknispjónustu liggja nú fyrir fjárlög fyrir árið 2020. Par kemur meðal annars fram að heildarframlög til heilbrigðismála nema 259.541 milljónum króna, um 26\% af heildarútgjöldum ríkissjóðs. Par af er 108,9 milljónum varið til sjúkrahúspjónustu og 57,9 milljónum í heilbrigðispjónustu utan sjúkrahúsa. Prátt fyrir aukin framlög til málaflokksins vantar nokkuð á að hægt verði að bæta pá pjónustu sem okkur er ætlað að sinna. Má par nefna aukinn launa- og rekstrarkostnað vegna langvarandi fjársveltis til eðlilegs viðhalds. Mun pví verulegur hluti pessa fjármagns fara í löngu tímabærar endurbætur og launaleiðréttingar.

Allflestar fjölskyldur í landinu purfa einhvern tíma á pjónustu heilbrigðiskerfisins að halda. Sem betur fer hafa flestar pjónustukannanir komið vel út í alpjóðlegum samanburði.

Pví miður hefur pað viðgengist um árabil að fjalla um rekstur pessa hornsteins almennrar velmegunar eins og um venjulegan fyrirtækjarekstur væri að ræða, án pess að taka mið af peirri framlegð sem pjónustan veitir beint og óbeint inn í efnahagslífið. Menn hafa ítrekað haldið pví fram að um taprekstur væri að ræða pegar í upphafi var kolvitlaust gefið! Hið rétta er að flestum Íslendingum er vel kunnugt um arðsemi pessarar pjónustu. Góð heilsa er forsenda pess að við getum verið virkir pátttakendur á vinnumarkaði. Staðreyndin er sú að á hverju ári væri hægt að reikna út pann gríðarlega arð sem pessi hornsteinn að velmegun og farsæld pjóðarinnar veitir inn í hagkerfið.

Eftirlits- og heilbrigðisstofnanir Bandaríkjanna hafa reiknað út hagnaðinn af pví að bjarga einu mannslífi, hann nemur 9,7 milljónum Bandaríkjadala. ${ }^{1}$ Ef tekið er mið af öllum viðmiðum, samfélagslegum, framlegðar til atvinnulífs, virkrar pátttöku í kaupum á pjónustu og fleira er árlegur hagnaður af hverju auknu lífsgæðavegnu lífári talinn vera 135.714 Bandaríkjadalir. Enginn ágreiningur er um fjárhagslegan ávinning pess að opna kransæð í hjartaáfalli, eða skipta um ónýta mjöðm vegna slitgigtar. Hins vegar höfum við ekki haldið á lofti kostnaðarlegri arðsemi af öðrum læknisverkum og lýðheilsuaðgerðum. Pannig hefur til dæmis nýlega verið reiknað út að árlegur sparnaður af pví að greina einstakling með undirliggjandi ónæmisgalla og hefja viðeigandi eftirlit og meðferð sé upp á tæpar 7 milljónir króna, jafnvel pó kostnaðarsamar reglulegar mótefnameðferðir séu viðhafðar. ${ }^{2}$ Pannig má ætla að árleg arðsemi af slíkri meðferð geti numið að minnsta kosti 150 milljónum króna!
Fjölmargar úttektir hafa verið gerðar á gæðum og afköstum íslensks heilbrigðiskerfis sem undantekingarlaust hafa sýnt að prátt fyrir að heildarframlög til málaflokksins séu eitthvert lægsta hlutfall af vergri landsframleiðslu sem pekkist á alpjóðavísu eru gæði og afköst með pví besta sem til pekkist. ${ }^{3}$

prátt fyrir góðan árangur er ljóst að veruleg tækifæri eru fyrir hendi til að auka arðsemi okkar heilbrigðiskerfis enn frekar. Almennt er talið að hlutfall tapaðs fjármagns innan heilbrigðiskerfisins geti numið 20-30\% á Vesturlöndum. Dæmi um slíkt er pegar sjúklingar eru sendir í læknisaðgerðir erlendis pótt sambærileg og jafnvel betri pjónusta sé í boði innanlands. Einnig er aðgengi sjúklinga að almennri læknispjónustu heilsugæslulækna óviðunandi. Vaxandi lyfjakostnaður hefur verið til umfjöllunar. Gerist petta á sama tíma og aðgengi að góðum og gömlum lyfjum (oftast ódýrum) verður sífellt erfiðara, auk pess sem sjúklingar fá oft ekki afgreidd lífsnauðsynleg lyf með tilheyrandi áhættu og auknum kostnaði. Í pví sambandi má nefna nýlega úttekt á gæðum nýrra lyfja á markaði fyrir árin 2011-2017 sem bendir til að eingöngu 25\% peirra hafi haft verulega mikil áhrif, en $58 \%$ fólu ekki í sér neina sjáanlega viðbót við eldri og oftast ódýrari meðferðarleiðir. ${ }^{4}$ Einnig hefur oft verið bent á möguleika samskiptamiðla til að stuðla að bættri og hagkvæmari heilbrigðispjónustu. ${ }^{5}$ Á undanförnum árum hafa orðið gríðarlegar framfarir í notkun gervigreindar og tölvuforrita með раð аð markmiði að stuðla að auknu aðgengi einstaklinga að lausnum til að taka frumkvæði að eigin heilsu. ${ }^{6}$ Undirritaður hefur ásamt samstarfsmönnum tekið pátt í pessari nýsköpun, en verulegur kostnaðarlegur ávinningur næst ef slíkar lausnir eru notaðar á markvissan máta., ${ }^{78}$ Pví miður hefur pessu verið tekið fálega í ráðuneyti heilbrigðismála fram til pessa, prátt fyrir að opinberlega sé rætt um mikilvægi slíkra lausna. Рað er með ólíkindum að við erum tilbúin að ræða um sjálfkeyrandi bíla, en erum enn langt á eftir í rafrænum lausnum til að styðja fólk í heilsueflandi aðgerðum og ekki síður til að styrkja lækna og heilbrigðisstarfsfólk í að veita bestu og arðsömustu pjónustuna.

Af framansögðu mætti vera ljóst að pað er löngu tímabært að við hættum að ræða um taprekstur heilbrigðiskerfisins, hann er einfaldlega ekki til staðar. Við megum pó ekki staðna í peirri viðleitni að gera gott kerfi betra og arðsamara. Par liggja fjölmörg sóknarfæri og er hér aðeins bent á örfá peirra.

Heimildir við leiðarann eru á heimasíðu blaðsins.

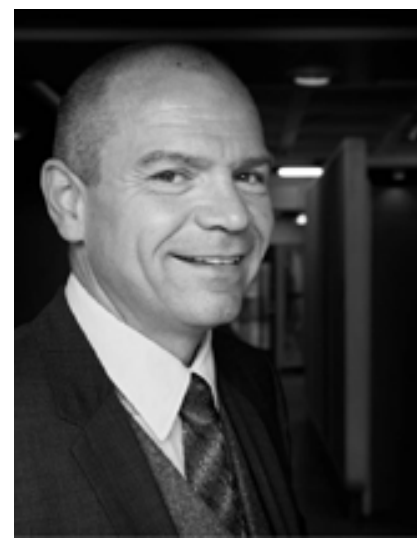

\section{Björn Rúnar Lúoví́ksson}

prófessor í ónæmisfræði, læknadeild Háskóla Íslands og ónæmisfræðideild Landspítala

bjornlud@landspitali.is

\section{The profitabilty of health care in Iceland}

Bjorn R. Ludviksson, MD, Ph.D. University of Iceland, Department of medicine, division of immunology, Landspitali University Hospital, Hringbraut, 101 Reykjavik, Iceland.

DOI: 10.17992/lbl.2019.10.249 